K.V. Chunikhin, V.S. Grinchenko

\title{
NORMALIZATION OF DOUBLE-CIRCUIT OVERHEAD LINE MAGNETIC FIELD INSIDE KHRUSHCHEV BUILDING
}

This paper deals with the mitigation of $110 \mathrm{kV}$ double-circuit overhead line magnetic field inside five-story Khrushchev buildings. We show that the magnetic field can exceed the reference level $0.5 \mu T$ in $90 \%$ part of living space. To mitigate the magnetic field, we propose the inverted L-shaped grid shield with conductors on the wall and in the attic of the building. Using the analytical model of the grid shield and the numerical simulation, we determine the parameters of the L-shaped grid shield which provides the magnetic field normalization in $97 \%$ part of living space. Further improvement of the grid shield profile, in particular, the placement of some conductors in the basement, allows to reduce the quantity of metal of the shield by $15 \%$ while maintaining the shielding efficiency. Also we consider the magnetic field normalization for the overhead line with a rated current of $500 \mathrm{~A}$. In this case, the quantity of metal of the grid shield increases 2.74 times. References 19, table 1, figures 5.

Key words: magnetic field, overhead line, grid shield, reference level, quantity of metal.

У роботі показано, щуо в п'ятиповерхових будинках хрущовської споруди, розташованих на гранииях охоронних зон двоколових повітряних ліній електропередачі $110 \kappa B$, величина магнітного поля промислової частоти може перевищувати гранично допустимий рівень 0,5 мкТл в 90 \% житлового простору. Для зменшення магнітного поля запропоновано використовувати Г-подібний тратчастий екран, проводи якого розташовуються на стіні та на горищі будинку. Шляхом аналітичного та чисельного моделювання визначено параметри Г-подібного тратчастого екрана, застосування якого дає змогу нормалізувати рівень магнітного поля в 97 \% житлового простору. Подальше вдосконалення профілю тратчастого екрана, зокрема, розміщення частини проводів у підвалі, дало змогу зменшити металоємність конструкиії на $15 \%$ при збереженні ефективності екранування. Також досліджено можливість нормалізації магнітного поля повітряної лінії $з$ номінальним струмом 500 А. У иььму випадку металоємність тратчастого екрана збільшується у 2,74 рази. Бібл. 19 , рис. 5 , табл. 1 .

Ключові слова: магнітне поле, повітряна лінія електропередачі, гратчастий екран, гранично допустимий рівень, металосмність.

В работе показано, что в пятиэтажных домах хрущевской постройки, расположенных на границах охранных зон двухиепных воздушных линий электропередачи 110 кB, величина магнитного поля промышленной частоты может превышать предельно допустимыгй уровень 0,5 мкТл в $90 \%$ жилого пространства. Для уменьшения магнитного поля предложено использовать Г-образный решетчатый экран, провода которого располагаются на стене и чердаке дома. Путем аналитического и численного моделирования определены параметры Г-образного решетчатого экрана, применение которого позволяет нормализовать уровень магнитного поля в $97 \%$ жсилого пространства. Дальнейшее совершенствование профиля решетчатого экрана, в частности, размещение части проводов в подвале, позволило уменьшить металлоемкость конструкции на 15 \% при сохранении эффективности экранирования. Также исследована возможность нормализачии магнитного поля воздушной линии с номинальным током 500 А. В этом случае металлоемкость решетчатого экрана увеличивается в 2,74 раза. Библ. 19, рис. 5, табл. 1.

Ключевые слова: магнитное поле, воздушная линия электропередачи, решетчатый экран, предельно допустимый уровень, металлоемкость.

Introduction. The Khrushchev era is known for its housing campaign. A vast number of housing square meters were built in USSR in sixties [1]. Usually these were five-story buildings made of prefabricated concrete blocks. That time the urban residential districts covered with such buildings (so-called Khrushchev buildings) appeared in many Soviet cities, especially industrial ones.

The overhead lines at voltages of 10 to $110 \mathrm{kV}$ are laid to supply both residential districts and adjacent industrial areas. The size of the right-of-way is set up in regulations. For example, in Ukraine the right-of-way is $20 \mathrm{~m}$ for $110 \mathrm{kV}$ overhead lines [2]. This corresponds with former Soviet requirements. At the same time, the requirements about the maximum permissible level (socalled reference level) of the power frequency magnetic field have changed significantly. The modern studies, particularly the "The International EMF Project" by the World Health Organization, have identified a high risk of the power frequency magnetic field for human health. It causes the world trend on stricter sanitary standards. Thus, Ukraine has accepted the reference level in $0.5 \mu \mathrm{T}$ for living spaces [3]. However, most residential buildings found near $110 \mathrm{kV}$ overhead lines do not meet this modern requirement. It is shown theoretically in $[4,5]$ and experimentally in [6], that the overhead line magnetic field exceeds the reference level. The degree of excess depends on the current flowing in conductors of the overhead line, the type of its tower, the distance from the overhead line to the building, and the height and the width of the building. Moreover, the power frequency magnetic field penetrates inside buildings with almost no attenuation $[7,8]$.

The purpose of this work is to find a way of the magnetic field normalization inside Khrushchev buildings found near $110 \mathrm{kV}$ double-circuit overhead lines.

The most efficient way of the magnetic field normalization is to move away the source. But changes in overhead line routes are often impossible within the urban residential district. The reconstruction of the overhead line or its replacement by a high-voltage underground cable line requires significant costs. So, the most promising way of the magnetic field normalization inside residential buildings is shielding.

(C) K.V. Chunikhin, V.S. Grinchenko 
The various shields are used to normalize the magnetic field inside buildings found near overhead lines, namely electromagnetic shields $[9,10]$, passive loops $[11,12]$, and active loops $[13,14]$. The active loops provide the comparably high shielding efficiency, but their price and expenses for maintenance checkup are relatively high as well. Passive loops are free of both these disadvantages, but their shielding efficiency is several times lower. Electromagnetic shields installed on building walls are most widely used to mitigate the magnetic field inside. However, electromagnetic shields consist of aluminum plates and therefore cannot cover windows. As well the mounting plates to the wall can cause difficulties.

A new type of shield is represented in $[15,16]$. Socalled grid shields consist of aluminum conductors connected in parallel. The recent research shows that grid shields are efficient for the magnetic field normalization inside high-rise buildings. But the magnetic field normalization inside five-story Khrushchev buildings was not studied.

Overhead line magnetic field inside Khrushchev building. Various series of five-story buildings were used during the Khrushchev housing campaign. However, the height and the width of the building did not change significantly. We assume that the height of the building is $16 \mathrm{~m}$, and the width is $12 \mathrm{~m} \mathrm{[17].} \mathrm{In} \mathrm{figures} \mathrm{below} \mathrm{the}$ contour of the building is marked by the dotted line.

Within this research we consider the double-circuit overhead line magnetic field. In [16] we analyzed towers and found that geometric sizes of P110-4V tower (transliterated from $\Pi 110-4 B$ ) are close to average ones. So, we assume the following values for the distances $a_{k}$ from the tower to conductors and for the heights $h_{k}$ of conductors: $a_{1}=a_{6}=2.1 \mathrm{~m}, \quad h_{1}=h_{6}=19 \mathrm{~m}, a_{2}=a_{5}=4.2 \mathrm{~m}$, $h_{2}=h_{5}=23 \mathrm{~m}, a_{3}=a_{4}=2.1 \mathrm{~m}, h_{3}=h_{4}=27 \mathrm{~m}$, where subscripts correspond to numbers of overhead line conductors (Fig. 1). As mentioned before, the distance between the conductor no. 2 and the building is $20 \mathrm{~m} \mathrm{[2].}$

The overhead line magnetic field strongly depends on the configuration of initial phases of conductor currents and the current amplitude. We consider the case when the magnetic field is the highest. So, the initial phases are the following: $\varphi_{1}=\varphi_{6}=-2 \pi / 3, \quad \varphi_{2}=\varphi_{5}=0$, $\varphi_{3}=\varphi_{4}=2 \pi / 3$. The RMS value of current in conductors is $262 \mathrm{~A}$, which corresponds to the $110 \mathrm{kV}$ double-circuit overhead line with transmission capacity $100 \mathrm{MW}$.

To find the overhead line magnetic field distribution, we use traditional assumptions, that conductors are infinitely long, parallel to each other and to the ground. So, we consider the overhead line magnetic field in the plane-parallel approach. This allows applying analytical expressions from [16] to find the magnetic field distribution inside the Khrushchev building. As well we can use the calculation technique from [18]. Fig. 1 shows that the magnetic field exceeds the reference level $0.5 \mu \mathrm{T}$ in most part of the building. For quantitative assessment we use the normalization index $\eta$. It is defined as a ratio of the space, in which the magnetic field does not exceed the reference level, to the entire living space. As the magnetic field is plane-parallel, the normalization index $\eta$ is the ratio of corresponding cross-sections $S$ and $S_{0}$ [16].

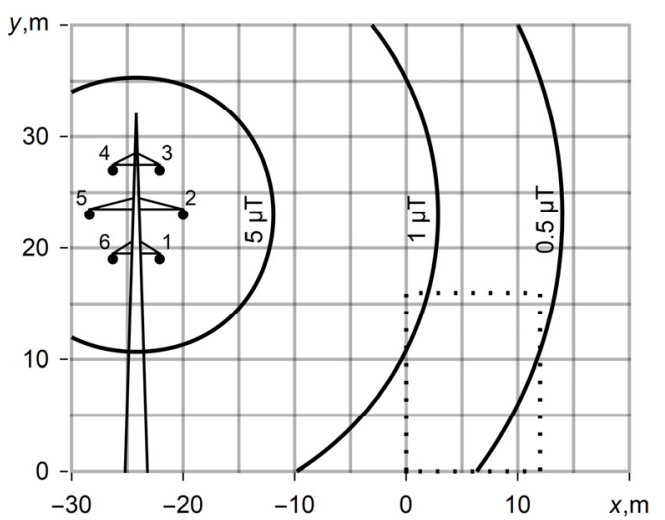

Fig. 1. Double-circuit overhead line magnetic field inside Khrushchev building (its contour is marked by dotted line)

According to [2], the areas closer than $0.5 \mathrm{~m}$ to walls are not considered. Also we do not consider the attic and the basement which are $1 \mathrm{~m}$ height. So, the cross-section of the building is $S_{0}=154 \mathrm{~m}^{2}$. Fig. 1 shows that the crosssection of space with permissible magnetic field is $S=16.8 \mathrm{~m}^{2}$. Correspondently, the normalization index $\eta=10.9 \%$.

Normalization of overhead line magnetic field. It is shown in $[15,16]$ that U-shaped grid shields are efficient for magnetic field normalization in high-rise buildings. However, the inverted L-shape looks more suitable for the lower Khrushchev building.

In the first step we consider grid shields with conductors on the wall faced to the overhead line and in the attic. The electrical conductivity of the grid shield is equal to $3.5 \cdot 10^{7} \mathrm{~S} / \mathrm{m}$. The distance between conductors is $0.5 \mathrm{~m}$. The axe of the corner conductor has coordinates $x=0, y=16 \mathrm{~m}$. We vary the number of conductors on the wall up to 33 . In the end case the conductors fill the whole wall and correspondently the extreme conductor has coordinates $x=0, y=0$. Also we vary the number of conductors in the attic up to 24 . In this end case the extreme conductor has coordinates $x=12 \mathrm{~m}, y=16 \mathrm{~m}$. We use the following nomenclature when varying the crosssection of conductors: $5,6,8,10,16,25,35$ and $50 \mathrm{~mm}^{2}$. To analyze shielding efficiency in each case, we use both the finite-element model from [15] and the semianalytical model from [19].

As the result we obtain the inverted L-shaped grid shield made of conductors with the cross-section of $25 \mathrm{~mm}^{2}$. The total number of conductors is 53: the attic is covered by 24 conductors, and 29 conductors are on the wall. Correspondently the extreme conductor has coordinates $x=0, y=2 \mathrm{~m}$. The profile of conductor placement is shown in Fig. 2 by the solid line.

Fig. 2 shows that the shielded magnetic field exceeds the reference level $0.5 \mu \mathrm{T}$ only in comparably small corner areas, and the normalization index $\eta$ becomes $97.2 \%$.

In the second step we use Wolfram Mathematica built-in functions of optimization to find the grid shield with the reduced quantity of metal while keeping the shielding efficiency. The obtained profile of the grid shield is shown in Fig. 3. The optimized grid shield consists of three sections connected in parallel. 


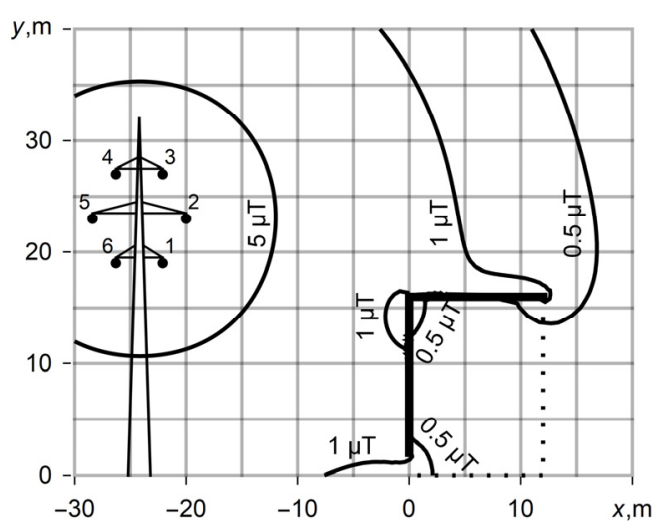

Fig. 2. Magnetic field distribution when using inverted L-shaped grid shield

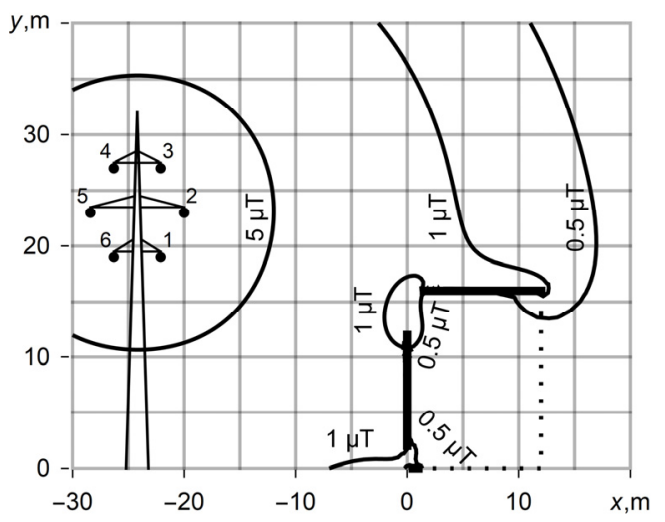

Fig. 3. Magnetic field distribution when using optimized grid shield

The section in the attic has 22 conductors arranged in the interval $1.5 \mathrm{~m} \leq x \leq 12 \mathrm{~m}$ when $y=16 \mathrm{~m}$. The section on the wall has 21 conductors in the interval $2 \mathrm{~m} \leq y \leq 12 \mathrm{~m}$ when $x=0$. Also there are two conductors in the basement. Their coordinates are $x=0.5 \mathrm{~m}, y=0$ and $x=1 \mathrm{~m}, y=0$. The total number of conductors is 45 . The cross-section of each conductor is $25 \mathrm{~mm}^{2}$. The quantity of metal of the optimized grid shield we appoint as $V_{1}$. The analysis of the magnetic field distribution from Fig. 3 gives the normalization index $\eta=97.1 \%$. So, the optimized grid shield allows reducing the quantity of metal by 15 percent in comparison with inverted L-shaped grid shield.

We study the efficiency of the optimized grid shield varying its quantity of metal (see column $a$ in Table 1). Also we compare it with efficiencies of grid shields having the following profiles (as before the distance between conductors is $0.5 \mathrm{~m}$ ):

- the inverted L-shaped grid shield (made of 45 conductors) with $16 \mathrm{~m}$ height vertical section and $6 \mathrm{~m}$ long upper horizontal section (see column $b$ in Table 1);

- the inverted L-shaped grid shield (made of 57 conductors) with $16 \mathrm{~m}$ height vertical section and $12 \mathrm{~m}$ long upper horizontal section (see column $c$ );

- the U-shaped grid shield (made of 69 conductors) with $16 \mathrm{~m}$ height vertical section, $12 \mathrm{~m}$ long upper horizontal section, and $6 \mathrm{~m}$ long bottom horizontal section (see column $d$ );

- the U-shaped grid shield (made of 81 conductors) with $16 \mathrm{~m}$ height vertical section and $12 \mathrm{~m}$ long horizontal sections (see column $e$ ).
Table 1

Normalization index $\eta$ for Khrushchev building found near double-circuit overhead line when using grid shield with quantity of metal equaled $V$

\begin{tabular}{|c|c|c|c|c|c|}
\hline \multirow{2}{*}{$V / V_{1}$} & \multicolumn{5}{|c|}{$\eta, \%$} \\
\cline { 2 - 6 } & $a$ & $b$ & $c$ & $d$ & $e$ \\
\hline 0.25 & 25.4 & 20.6 & 21.5 & 22.2 & 19.4 \\
\hline 0.5 & 70.7 & 46.9 & 54.8 & 43.7 & 36.2 \\
\hline 0.75 & 92.8 & 60.7 & 85.2 & 72.6 & 58.8 \\
\hline 1 & 97.1 & 68.4 & 95.2 & 89.2 & 82.8 \\
\hline 1.25 & 98.5 & 73.8 & 98.1 & 95.5 & 92.2 \\
\hline
\end{tabular}

As grid shields $a-e$ contain different number of conductors, we consider different conductor crosssections to achieve the equality of total quantities of metal.

The obtained results show that efficiencies of the optimized shield and the grid shield type $c$ are comparable. However, the practical implementation of the grid shield type $c$ is difficult as it uses conductors with off-standard cross-section $19.7 \mathrm{~mm}^{2}$. So, the usage of the optimized grid shield is recommended. Table 1 shows that the increase or the decrease of its quantity of metal is impractical.

Overhead line with increased conductor current. Additionally, we consider the overhead line magnetic field normalization when the conductor current is $500 \mathrm{~A}$ $[5,11]$. In this case the magnetic field exceeds the reference level $0.5 \mu \mathrm{T}$ in the whole building (Fig. 4). Moreover, the fourfold magnetic field mitigation is needed in apartments faced to the overhead line. To normalize the magnetic field, we develop the grid shield made of 62 conductors (Fig. 5). The cross-section of each conductor is $50 \mathrm{~mm}^{2}$. Correspondently the quantity of metal of the shield is $2.74 \cdot V_{1}$. The distance between conductors is $0.5 \mathrm{~m}$. The arrangement of conductors is the following:

- 27 conductors cover the wall faced to the overhead line (their coordinates lay within the interval $1 \mathrm{~m} \leq y \leq 14 \mathrm{~m}$ when $x=0$ );

- 11 conductors are arranged on the back wall (within the interval $11 \mathrm{~m} \leq y \leq 16 \mathrm{~m}$ when $x=12 \mathrm{~m}$ );

- 22 conductors cover the attic (within the interval $0.5 \mathrm{~m} \leq x \leq 11 \mathrm{~m}$ when $y=16 \mathrm{~m})$;

- 2 conductors lay in the basement (in $x=0.5 \mathrm{~m}, y=0$ and $x=1 \mathrm{~m}, y=0)$.

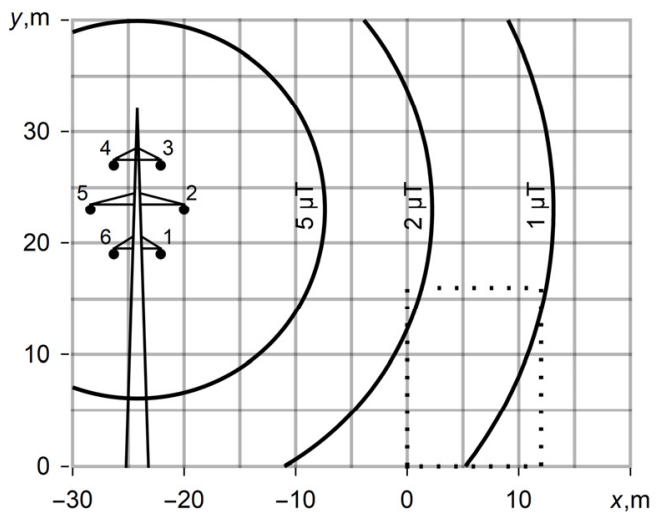

Fig. 4. Double-circuit overhead line magnetic field when conductor current is $500 \mathrm{~A}$ 


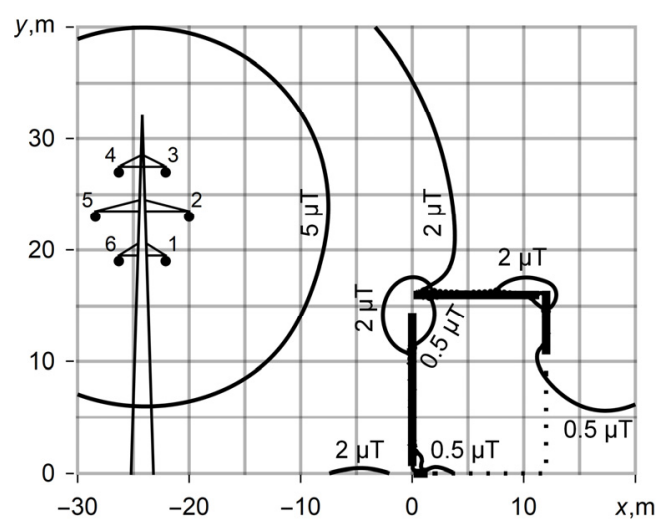

Fig. 5. Normalization of double-circuit overhead line magnetic field when conductor current is $500 \mathrm{~A}$

The usage of this grid shield allows to achieve the normalization index $\eta=97.1 \%$. Fig. 5 shows the distribution of the normalized magnetic field inside the Khrushchev building.

So, the obtained results show that grid shields are efficient in the magnetic field normalization inside Khrushchev buildings found near the overhead lines.

Conclusions.

1. Using the analytical model of the shield and the numerical simulation, we show that the inverted L-shaped grid shield made of aluminum conductors with a crosssection of $25 \mathrm{~mm}^{2}$ and mounted on the wall and in the attic of the Khrushchev building normalizes inside it the magnetic field produced by the $110 \mathrm{kV}$ double-circuit overhead line.

2 . We propose the specific grid shield that provides the shielding efficiency of the L-shaped shield and consumes the quantity of metal reduced by 15 percent. This shield consists of three sections of conductors, namely two sections cover the wall and the attic of the Khrushchev building, and two extra conductors are placed in the basement.

3. To normalize the $110 \mathrm{kV}$ double-circuit overhead line magnetic field with increased conductor current, we modify the arrangement of conductors on the wall faced to the line and in the attic, we add the extra section of conductors to the back wall and increase the cross-section of all conductors to $50 \mathrm{~mm}^{2}$.

Conflict of interest. The authors declare that they have no conflicts of interest.

\section{REFERENCES}

1. Reid S. Khrushchev Modern: Agency and modernization in the Soviet home. Cahiers du monde russe, 2006, no. 47, iss. 1, pp. 227-268. doi: https://doi.org/10.4000/monderusse.3800.

2. Decree of the Cabinet of Ministries of Ukraine dated March 4, 1997 No. 209 «About the statement of Rules of protection of electric networks», Edition on April 5, 2017. (Ukr).

3. Electrical installation regulations. Kharkiv, Fort Publ., 2017. 760 p. (Ukr).

4. Rozov V.Yu., Reutskyi S.Yu., Pelevin D.Ye., Pyliugina $\mathrm{O}$.Yu. The magnetic field of power transmission lines and the methods of its mitigation to a safe level. Technical Electrodynamics, 2013, no. 2, pp. 3-9. (Rus).

5. Pelevin D.Ye. The methods of reducing of the magnetic fields of overhead power lines outside security zones. Technical Electrodynamics, 2014, no. 5, pp. 14-16. (Rus).

6. Krasnozhon A.V., Buinyi R.O., Dihtyaruk I.V., Kvytsynskyi A.O. The investigation of distribution of the magnetic flux density of operating two-circuit power line $110 \mathrm{kV}$ «ChTPP-
Chernihiv-330» in the residential area and methods of its decreasing to a safe level. Electrical Engineering \& Electromechanics, 2020, no. 6, pp. 55-62. doi: https://doi.org/10.20998/2074-272X.2020.6.08.

7. Pelevin D.Ye. Screening magnetic fields of the power frequency by the walls of houses. Electrical Engineering \& Electromechanics, 2015, no. 4, pp. 53-55. (Rus). doi: https://doi.org/10.20998/2074-272X.2015.4.10.

8. Rozov V., Grinchenko V. Simulation and analysis of power frequency electromagnetic field in buildings closed to overhead lines. Proc. 2017 IEEE First Ukraine Conference on Electrical and Computer Engineering, Kyiv, Ukraine, pp. 500-503. doi: https://doi.org/10.1109/UKRCON.2017.8100538.

9. Cardelli E., Faba A., Pirani A. Nonferromagnetic open shields at industrial frequency rate. IEEE Transactions on Magnetics, 2010, vol. 46, no. 3, pp. 889-898. doi: https://doi.org/10.1109/TMAG.2009.2031110.

10. Bavastro D., Canova A., Freschi F., Giaccone L., Manca M. Magnetic field mitigation at power frequency: Design principles and case studies. IEEE Transactions on Industry Applications, 2015, vol. 51, no. 3, pp. 2009-2016. doi: https://doi.org/10.1109/TIA.2014.2369813.

11. Cruz P., et al. Magnetic field mitigation in power lines with passive and active loops. Proc. CIGRE Session, 2002, no. 36-107.

12. Budnik K., Machczynski W. Power line magnetic field mitigation using a passive loop conductor. Poznan University of Technology Academic Journals. Electrical Engineering, 2013, vol. 73, pp. 137-145.

13. Canova A., del-Pino-Lopez J.C., Giaccone L., Manca M. Active shielding system for ELF magnetic fields. IEEE Transactions on Magnetics, 2015, vol. 51, iss. 3. doi: https://doi.org/10.1109/TMAG.2014.2354515.

14. Kuznetsov B.I., Nikitina T.B., Bovdui I.V. High voltage power lines magnetic field system of active shielding with compensation coil different spatial arrangement. Electrical Engineering \& Electromechanics, 2019, no. 4, pp. 17-25. doi: https://doi.org/10.20998/2074-272X.2019.4.03.

15. Grinchenko V., Pyrohova U. Mitigation of overhead line magnetic field by U-shaped grid shield. Proc. 2019 IEEE Second Ukraine Conference on Electrical and Computer Engineering, Lviv, Ukraine, pp. 345-348. doi: https://doi.org/10.1109/UKRCON.2019.8879834.

16. Grinchenko V.S., Chunikhin K.V. Magnetic field normalization in residential building located near overhead line by grid shield. Electrical Engineering \& Electromechanics, 2020, no. 5, pp. 38-43. doi: https://doi.org/10.20998/2074272X.2020.5.06.

17. Koporovskii G.I., et al. Typical project 111-96-3. Residential buildings series 96. Kyiv, KyivZNIIEP Publ. (Rus). 18. SOU-N EE 20.179:2008. Calculation of electric and magnetic fields of power lines. Method (with changes). Kyiv, Minenergovugillja Ukrainy Publ., 2016. 37 p. (Ukr).

19. Grinchenko V.S. Development of a semi-analytical model of a grid shield for the magnetic field mitigation of overhead lines. Proc. VII All-Ukrainian Scientific Conf. of Young Scientists «Information Technologies - 2020», pp. 149-151. (Ukr).

Received 08.04.2021 Accepted 14.05.2021 Published 25.06.2021

\section{K.V. Chunikhin ${ }^{1}, P h D$,}

V.S. Grinchenko ${ }^{1}, P h D$,

${ }^{1}$ State Institution "Institute of Technical Problems of Magnetism of the National Academy of Sciences of Ukraine",

19, Industrialna Str., Kharkiv, 61106, Ukraine, e-mail:kvchunikhin@gmail.com,

vsgrinchenko@gmail.com (Corresponding author)

How to cite this article:

Chunikhin K.V., Grinchenko V.S. Normalization of double-circuit overhead line magnetic field inside Khrushchev building. Electrical Engineering \& Electromechanics, 2021, no. 3, pp. 38-41. doi: https://doi.org/10.20998/2074-272X.2021.3.06. 